\title{
Bowel and mesenteric injury in blunt trauma: Diagnostic efficiency and importance of experience in using multidetector computed tomography
}

\author{
Ahmet Veysel Polat, M.D., ${ }^{1}$ Ramazan Aydın, M.D., ${ }^{2}$ Mehmet Selim Nural, M.D., ${ }^{1}$ \\ Selim Baris Gul, M.D., ${ }^{1}$ Ayfer Kamali Polat, M.D., ${ }^{3}$ Kerim Aslan, M.D. ${ }^{1}$
}

${ }^{1}$ Department of Radiology, Ondokuz Mayıs University Faculty of Medicine, Samsun;

${ }^{2}$ Department of Radiology, Samsun Training and Research Hospital, Samsun;

${ }^{3}$ Department of General Surgery, Ondokuz Mayıs University Faculty of Medicine, Samsun

\begin{abstract}
BACKGROUND: The purpose of this study was to investigate the diagnostic efficiency of multidetector computed tomography (MDCT) in the detection of blunt bowel and mesenteric injuries (BBMI), and the role of different experience levels in using MDCT.

METHODS: This study included a test group of twenty-seven patients with surgically important BBMI in whom the diagnoses were confirmed after surgical intervention ( 23 men and 4 women; mean age, $40.7 \pm 16.2$; range, 18-76), and a control group of twenty-one matched patients without BBMI who underwent laparotomy for trauma during the same time period ( 16 men and 5 women; mean

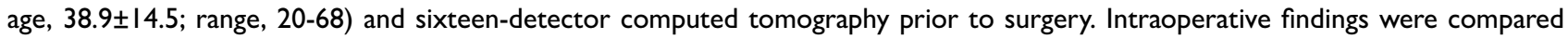
with MDCT findings.
\end{abstract}

RESULTS: High accuracy, specificity, and positive predictive values in MDCT findings with respect to intraperitoneal free air, mesenteric air, thickened (>4-5 mm) and defected bowel wall, increased contrast enhancement on bowel wall, and mesenteric hematoma were found among others $(p<0.01)$. Sensitivities and specificities of the diagnosis of BBMI by the resident and staff radiologist was $74 \%$ and $71 \%$, and $85 \%$ and $100 \%$, respectively.

CONCLUSION: MDCT displays BBMI with high sensitivity and specificity, and can predict the need for surgery. Experience in radiology is an important factor for appropriate interpretation of the MDCT findings.

Key words: Blunt abdominal trauma; bowel injury; multidetector computed tomography.

\section{INTRODUCTION}

Blunt bowel and mesenteric injuries (BBMI) are rare injuries with high morbidity and mortality, and occur in only $1-5 \%$ of blunt abdominal traumas. ${ }^{[1-4]}$ Accurate diagnosis is of great importance since delayed diagnosis of BBMI may result in serious complications and mortality. Early diagnosis of isolated $B B M I$ is difficult in patients with blunt abdominal trauma as

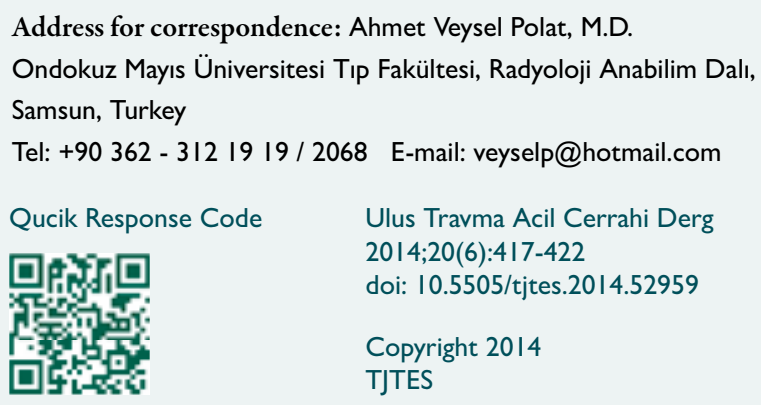

clinically apparent signs and symptoms of peritonitis caused by perforation can be observed only after a considerable period of time, causing delayed diagnosis. As a result of delay in diagnosis, intraabdominal complications, such as abscess, sepsis, and even mortality, can be seen after surgical repair. [5-7] Signs and symptoms of peritonitis like rigidity, tenderness, and rebound are sometimes undetectable, and abdominal examination findings may be obscure in patients critically injured or neurologically compromised or in those experiencing an altered sensorium resulting from drugs, alcohol intoxication, or central nervous system trauma simultaneously. Currently, the diagnostic modalities besides physical examinations are paracentesis, diagnostic peritoneal lavage, focused abdominal sonogram for trauma, computed tomography (CT) scan, and laparoscopy. ${ }^{[7-15]}$ Multidetector computed tomography (MDCT) is an excellent imaging modality for diagnosing and managing patients with abdominal injuries while playing critical role in describing and grading solid-organ injuries, diagnosing the significance of BBMI, and deciding whether surgical 
intervention is required. If patients are hemodynamically unstable, detection of suspected bowel and mesenteric injuries is necessary for emergency surgical treatment. ${ }^{[4-7]}$ However, if patients are hemodynamically stable and no suspicious BBMI is present on MDCT, nonsurgical management is the acceptable standard care for blunt abdominal trauma. However, the true contribution of MDCT in diagnosing BBMI is controversial; $\left[{ }^{[6,17]}\right.$ there is a wide spectrum of signs correlating with the type, site, and extent of damage on CT. ${ }^{[4]}$ Although CT imaging technology and interpretation has improved greatly in the past decade in terms of detection or exclusion of BBMI, controversy still remains as to how reliable MDCT is in distinguishing surgical from nonsurgical bowel and mesenteric injury. ${ }^{[5]}$

The main goals of this study were to investigate the diagnostic accuracy of MDCT in the detection of bowel and mesenteric injuries, and evaluate the concordance of MDCT findings of BBMI with surgical observations and with different experience levels in radiology.

\section{MATERIALS AND METHODS}

The ethics committee of our hospital approved this retrospective case-control study and waived the requirement for informed patient consent.

\section{Patients}

Totally, two thousand nine hundred and twenty-three patients with blunt abdominal trauma between January 2007 and December 2012 were enrolled. The test group comprised twenty-seven patients with surgically important BBMI whose diagnoses were confirmed after surgical intervention (23 men and 4 women; mean age, 40.74 16.2 years; age range, 18-76 years). The control group comprised twentyone matched patients without BBMI who underwent laparotomy for trauma during the same time period (16 men and 5 women; mean age, 38.9 14.5 years; age range, 20-68 years) and sixteen-detector computed tomography prior to surgery. Intraoperative findings were compared with MDCT findings.

\section{MDCT Technique and Interpretation}

MDCT scans were obtained using a 16-row multidetector CT scanner (Aquilion 16; Toshiba Medical Systems Corporation, Japan). The scanning parameters were as follows: $150 \mathrm{mAs}$; $120 \mathrm{kV}$; collimation, $2 \times 16 \mathrm{~mm}$; pitch, I; section thickness, 3 $\mathrm{mm}$; reconstruction interval, $\mathrm{I} \mathrm{mm}$; and tube rotation period, $0.5 \mathrm{~s}$. Intravenous iodinated contrast was given according to protocol: $100-120 \mathrm{ml}$ of $350 \mathrm{mg} / \mathrm{ml}$ contrast at $3 \mathrm{ml} / \mathrm{s}$. Oral contrast $(\mathrm{OC})$ was not used routinely due to current controversy on using $O C$ in trauma patients. $O C$ use in trauma patients may sometimes cause cervical restraints, a supine position, intoxication, diminished sensorium, nausea, vomiting, need for a nasogastric tube, risks of aspiration, and time constraints with limited visualization of the intestinal tract ${ }^{[10]}$; only five patients were administered $\mathrm{OC}$ in this study. For single-phase imaging, post-contrast images of the abdomen and pelvis were acquired at $70 \mathrm{~s}$. When necessary, sagittal and coronal images were acquired using the multiplanar reconstruction technique. Scans were also evaluated using the "lung or bone" windows that helped differentiate between abdominal fat and air.

In order to assess the accuracy of different levels of experience on radiology, all CT scans were reevaluated independently by a fourth-year radiology resident and a staff abdominal radiologist, both of whom were blinded to the patients' final outcomes and the initial radiological reports. All evaluations were reviewed using our department's picture archiving and communicating system on liquid crystal display monitors, and the probability of BBMI was recorded. Coronal and sagittal CT reconstructions were available for review, if necessary. Numerous CT signs of bowel and mesenteric injury secondary to blunt trauma have been described in the literature, and our CT findings were based on these descriptions. ${ }^{[17,18]} \mathrm{CT}$ signs of BBMI are intraperitoneal air, retroperitoneal air, mesenteric air, thick bowel wall, abnormal bowel wall enhancement, bowel wall defect, intraperitoneal fluid, retroperitoneal fluid, focal mesenteric hematoma, mesenteric fluid, and mesenteric stranding.

\section{Statistical Analyses}

The $\mathrm{X}^{2}$ test was used for the comparison of categorical variables; the Wilcoxon rank-sum test was used for the comparison of continuous variables. Sensitivity, specificity, and positive and negative predictive values were calculated for each reader and each MDCT sign. For evaluating concordance of the diagnoses of BBMI by the two readers, kappa ratio was calculated for each reader. According to the criteria of Landis and Koch, ${ }^{[19]}$ a kappa value of less than 0 indicated less agreement than expected by chance; $0-0.20$, slight agreement; 0.2I-0.40, fair agreement; 0.4I-0.60, moderate agreement; 0.6I-0.80, substantial agreement; 0.8I-0.99, almost perfect agreement; and I.0, perfect agreement. Positive and negative likelihood ratios were calculated for individual MDCT signs. $A$ value of $p<0.05$ was considered to be significant.

\section{RESULTS}

Twenty-seven (56\%) of 48 patients had surgically proven BBMI and 2 I (44\%) patients had no BBMI. The BBMI rate detected on MDCT in our study was $0.9 \%(27 / 2923)$. Of the twenty-seven patients with BBMI, 20 (74\%) had bowel injury, 3 (II\%) had mesenteric injury, and 4 (15\%) had bowel and mesenteric injury. The localizations of bowel injury were the ileum, 12 (50\%); jejunum, 6 (25\%); colon, 3 (I3\%); jejunumileum, 2 (8\%); and ileum-colon, I (4\%). Forty-two (88\%) patients had been involved in a motor vehicle accident. Of the remaining six injuries, four resulted from falls and two form industrial accidents. Peritoneal lavage was not performed for 


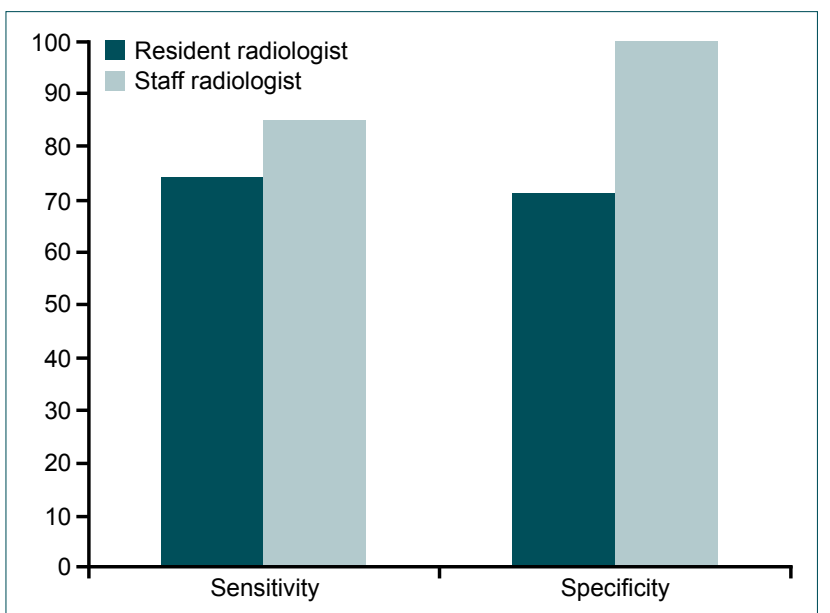

Figure 1. Graph shows diagnostic performance of staff and resident radiologist.

any of the patients. OC was not used routinely; only five patients were given $\mathrm{OC}$ in our study.

Sensitivities of the resident and staff radiologist in the diagnosis of bowel and/or mesenteric injury ranged from $74 \%$ to $85 \%$ and the specificities ranged from $71 \%$ to $100 \%$; falsenegative case numbers were 9 and 4 and false-positive case numbers were 2 and 0 , respectively (Fig. I).

High accuracy, specificity, and positive predictive values for MDCT findings in terms of intraperitoneal free air, mesenteric air, thickened (>4-5 mm) bowel wall, increased contrast enhancement on bowel wall, bowel wall defect, and mesenteric hematoma were found among others (Table I). Intraperitoneal free air (Fig. 2a), mesenteric air (Fig. 2b), thick large bowel (Fig. 2c), increased bowel wall enhancement (Fig. 2c), bowel wall defect (Fig. 2d), focal mesenteric hematoma, and mesenteric fluid and mesenteric stranding (Fig. 2e) showed the best positive likelihood ratios for bowel and/or mesenteric injury. MDCT findings, reviewed by the staff radiologist, were given in Table 2 according to the injury type. The differences in detecting BBMI were statistically significant among readers evaluating inter-observer agreement between reviewers $(p<0.01)$. In case of the staff radiologist, the concordance of the CT findings and operative findings was excellent (kappa ratio: $0.834[0.8 \mathrm{I}-\mathrm{I}$, excellent $]$ ).

\section{DISCUSSION}

MDCT significantly affects the decision on managing non-operative patients without BBMI but with isolated solid-organ injuries. However, the diagnosis of patients with suspected BBMI after blunt trauma is a dilemma and clinical diagnosis of BBMI and differentiation of those requiring surgery from those that can heal clinically is the main problem. ${ }^{[16,17]}$

Although CT is the best noninvasive modality presently available to diagnose BBMI, several studies report that only CT is unreliable in diagnosing BBMI. ${ }^{[5,10,17]}$ Sharma et al. reported that BBMI was not initially diagnosed in 35\% (8 of 23) of the patients. ${ }^{[10]}$ Bhagvan et al. ${ }^{[17]}$ stated that the false-negative CT scan incidence was $13 \%$ in five hundred and fifty-eight patients with small bowel perforation. It is considered necessary to conduct an urgent exploration for any unexplained and nonspecific CT scan findings in patients with more than one suspicious finding for bowel or mesenteric injury on the CT scan due to the possibility of false negativity. ${ }^{[10]}$ In our study, the false-negative rate was $14.8 \%$ (4/27) for the staff radiologist and $33.3 \%$ (9/27) for the radiology resident. In terms of evaluations of CT findings, in this study, high accuracy, speci-

Table I. Sensitivity, specificity, and likelihood ratios of various signs in identifying surgically important bowel and/or mesenteric injury

\begin{tabular}{lcccccc}
\hline & & & & \multicolumn{2}{c}{ Likelihood Ratio } \\
\cline { 2 - 6 } Sign & Sensitivity (\%) & Specificity (\%) & PPV (\%) & NPV (\%) & Positive & Negative \\
\hline Intraperitoneal air & 33 & 100 & 100 & 53 & Infinity* & 0.67 \\
Retroperitoneal air & 11 & 85 & 50 & 42 & 0.73 & 1.04 \\
Mesenteric air & 41 & 100 & 100 & 56 & Infinity* & 0.59 \\
Thick bowel wall & 52 & 91 & 87 & 60 & 5.7 & 0.52 \\
Abnormal bowel wall enhancement & 52 & 100 & 100 & 62 & Infinity* & 0.48 \\
Bowel wall defect & 26 & 100 & 100 & 51 & Infinity* & 0.74 \\
Intraperitoneal fluid & 81 & 33 & 61 & 58 & 1.2 & 0.58 \\
Retroperitoneal fluid & 41 & 42 & 48 & 36 & 0.79 & 1.4 \\
Focal mesenteric hematoma & 19 & 95 & 83 & 48 & 3.8 & 0.85 \\
Mesenteric fluid & 52 & 95 & 93 & 61 & 10.4 & 0.5 \\
Mesenteric stranding & 81 & 76 & 81 & 76 & 3.4
\end{tabular}

PPV: Positive predictive value; NPV: Negative predictive value, *: This likelihood ratio is considered useful in clinical practice. 
Table 2. Relations of individual CT signs with injury type

\begin{tabular}{|c|c|c|c|c|c|c|}
\hline \multirow{3}{*}{ Sign } & \multicolumn{6}{|c|}{ Injury type } \\
\hline & \multicolumn{2}{|c|}{ Bowel injury $(n=20)$} & \multicolumn{2}{|c|}{ Mesenteric injury $(n=3)$} & \multicolumn{2}{|c|}{ Bowel and mesenteric injury $(n=4)$} \\
\hline & $\mathbf{n}$ & $\%$ & $\mathbf{n}$ & $\%$ & $\mathbf{n}$ & $\%$ \\
\hline Intraperitoneal air & 8 & 40 & 0 & 0 & I & 25 \\
\hline Retroperitoneal air & 2 & 10 & 0 & 0 & I & 25 \\
\hline Mesenteric air & 9 & 45 & 0 & 0 & 2 & 50 \\
\hline Thick bowel wall & 13 & 65 & 0 & 0 & I & 25 \\
\hline Abnormal bowel wall enhancement & 13 & 65 & 0 & 0 & I & 25 \\
\hline Bowel wall defect & 5 & 25 & 0 & 0 & 2 & 50 \\
\hline Intraperitoneal fluid & 17 & 85 & 3 & 100 & 2 & 50 \\
\hline Retroperitoneal fluid & 6 & 30 & 2 & 67 & 3 & 75 \\
\hline Focal mesenteric hematoma & 3 & 15 & 2 & 67 & 0 & 0 \\
\hline Mesenteric fluid & 13 & 65 & 1 & 33 & 0 & 0 \\
\hline Mesenteric stranding & 17 & 85 & 3 & 100 & 2 & 50 \\
\hline
\end{tabular}

ficity, and positive predictive values in terms of intraperitoneal free air, mesenteric air, bowel wall thickening, and increased contrast enhancement on bowel wall, bowel wall defect, and mesenteric hematoma were found among others.

Besides the difficulty in performing a CT diagnosis, it warrants optimal technique and skilled interpretation. Atri et al. have found that the staff radiologist is significantly more accurate than the resident in identifying mesenteric injuries $(p<0.01)$. In case of surgically important bowel injuries, significant differences were observed between the sensitivity and specificity values of the staff radiologist and those of the trainees (resident and fellow). ${ }^{[4]}$ In the present study, the difference in detecting BBMI in terms of sensitivity and specificity were statistically significant between the two readers $(p<0.01)$. The concordance of the CT findings with the operative results was excellent in the case of the experienced radiologist (kappa ratio: 0.834).

Several studies report on discrepancies in CT interpretations by residents and staffs. Tieng et al. have reported a $10 \%$ discrepancy rate. ${ }^{[20]}$ Yoon et al. ${ }^{[21]}$ have found a $29.9 \%$ discrepancy rate in their study. In this study, the false-negative rates were $8.3 \%(4 / 48)$ for the staff radiologist and $18.75 \%(9 / 48)$ for the resident. The staff radiologist had no false-positive rate but the resident had two false positives $(4 \%, 2 / 48)$ in our cohort. While our discrepancy rate is moderate at $14.6 \%$
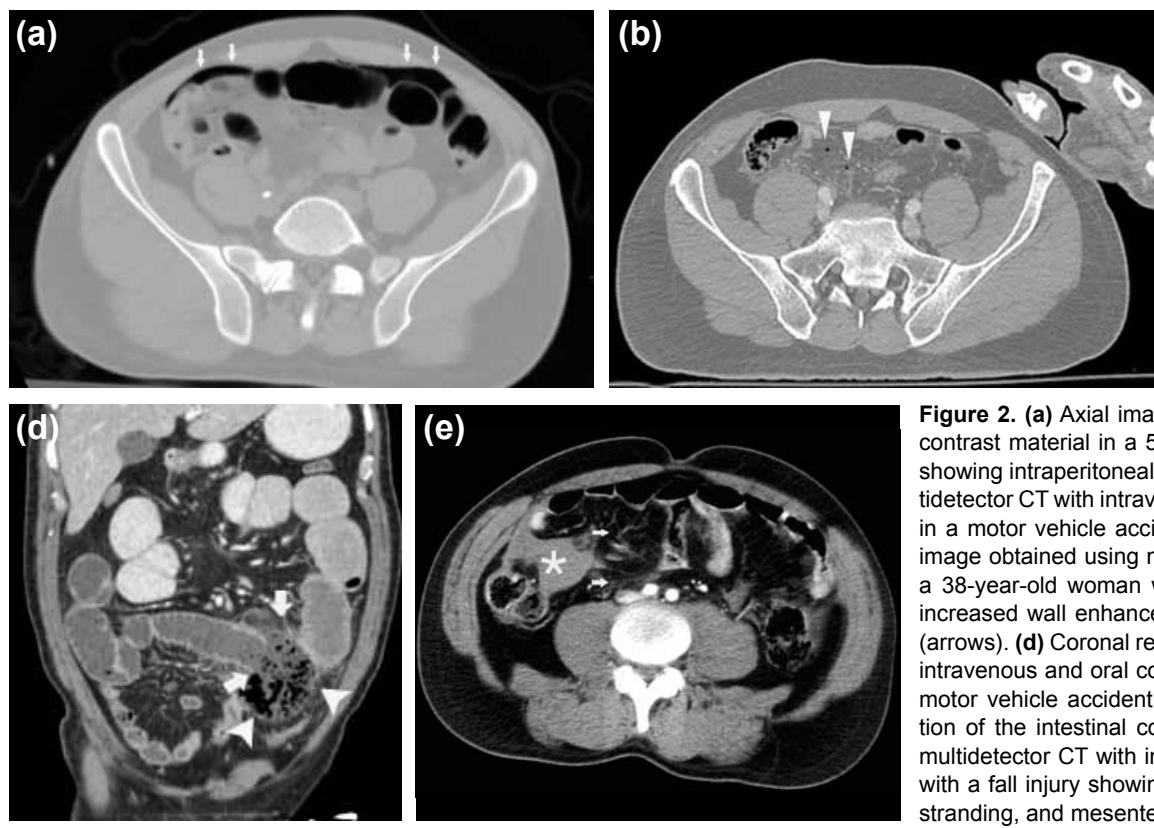

Figure 2. (a) Axial image obtained using multidetector CT with intravenous contrast material in a 55-year-old man involved in a motor vehicle accident showing intraperitoneal free air (arrows). (b) Axial image obtained using multidetector CT with intravenous contrast material in a 45-year-old man involved in a motor vehicle accident showing mesenteric air (arrowheads). (c) Axial image obtained using multidetector CT with intravenous contrast material in a 38-year-old woman with a fall injury showing bowel wall thickening and increased wall enhancement of the small bowels at the left lower quadrant (arrows). (d) Coronal reformatted image obtained using multidetector CT with intravenous and oral contrast material in a 19-year-old woman involved in a motor vehicle accident showing bowel wall defect (arrows) and extravasation of the intestinal content (arrowheads). (e) Axial image obtained using multidetector CT with intravenous contrast material in a 57-year-old woman with a fall injury showing focal mesenteric hematoma (asterisk), mesenteric stranding, and mesenteric fluid (arrows). 
(7/48), it cannot be guaranteed in the current practice. Even one case is very important and if it were to be concluded, a terrific result would have occurred due to this discrepancy. As in many countries, in our institute, general workflow in terms of daily practice is the interpretation given at night by residents. After this initial resident interpretation, secondary review is performed by a staff radiologist within $24 \mathrm{~h}$. This delay may sometimes cause mortality; teleradiology may be a solution for preventing this kind of time delay and consulting with experts during off-hours.

Teleradiology interpretations may assist emergency physicians in making appropriate medical decisions and radiology residents provide initial readings and prevent discrepancies during off-hours. Teleradiology is defined as the electronic transmission of radiographic images between two geographical locations for the purposes of interpretation and consultation. In countries with picture archiving and communication system (PACS) integrated in a regional or national network, image distribution can be organized in a cross-enterprise fashion. In many European countries and in the United States, a large teleradiology network has been established and the DICOM-email is the accepted standard. In several hospitals, teleradiology has become a part of the regular workflow. Image distribution using PACS support home-based (on call) radiologists in emergency situations. ${ }^{[22,23]}$

There are several limitations to this study. It was retrospective; patients of a specific period of time were reviewed and only patients with blunt abdominal trauma were evaluated. In addition, the $\mathrm{CT}$ finding readers were aware of the patients surgically treated but were blinded for the surgical reports; this might have forced the readers to try to find a pathological finding on the CT scans. However, since the staff and resident were informed of the cases in the same manner, no differences existed in the distribution of information to both readers. Moreover, as the CT findings were compared with operative findings, only surgically treated patients were included into the study. In addition, this study included a small number of surgically proven BBMI cases.

Experience in radiology is an important factor causing differences in the interpretation of CT findings and making CT examination more sensitive and specific in terms of decisionmaking on the clinical management (surgery or nonsurgical follow-up). Awareness of BBMI findings on CT scans and experience increase the diagnostic accuracy of $C T$. However, diagnosis of BBMI is difficult and CT cannot be used as the only diagnostic tool. Close clinical observation, monitoring, and surgical expertise are mandatory for appropriate management. Teleradiology may help in reporting cases from out of hospital and may help to avoid discrepancies. Further studies are needed to better define the sensitivity of teleradiological interpretations for identifying the pathology of trauma.

Conflict of interest: None declared.

\section{REFERENCES}

1. Holmes JF, Offerman SR, Chang CH, Randel BE, Hahn DD, Frankovsky MJ, et al. Performance of helical computed tomography without oral contrast for the detection of gastrointestinal injuries. Ann Emerg Med 2004;43:120-8. CrossRef

2. Killeen KL, Shanmuganathan K, Poletti PA, Cooper C, Mirvis SE. Helical computed tomography of bowel and mesenteric injuries. J Trauma 2001;51:26-36. CrossRef

3. Watts DD, Fakhry SM; EAST Multi-Institutional Hollow Viscus Injury Research Group. Incidence of hollow viscus injury in blunt trauma: an analysis from 275,557 trauma admissions from the East multi-institutional trial. J Trauma 2003;54:289-94. CrossRef

4. Atri M, Hanson JM, Grinblat L, Brofman N, Chughtai T, Tomlinson G. Surgically important bowel and/or mesenteric injury in blunt trauma: accuracy of multidetector CT for evaluation. Radiology 2008;249:52433. CrossRef

5. Scaglione M, de Lutio di Castelguidone E, Scialpi M, Merola S, Diettrich AI, Lombardo P, et al. Blunt trauma to the gastrointestinal tract and mesentery: is there a role for helical CT in the decision-making process? Eur J Radiol 2004;50:67-73. CrossRef

6. Fakhry SM, Brownstein M, Watts DD, Baker CC, Oller D. Relatively short diagnostic delays ( $<8$ hours) produce morbidity and mortality in blunt small bowel injury: an analysis of time to operative intervention in 198 patients from a multicenter experience. J Trauma 2000;48:408-14.

7. Rodriguez A, DuPriest RW Jr, Shatney CH. Recognition of intra-abdominal injury in blunt trauma victims. A prospective study comparing physical examination with peritoneal lavage. Am Surg 1982;48:457-9.

8. Drost TF, Rosemurgy AS, Kearney RE, Roberts P. Diagnostic peritoneal lavage. Limited indications due to evolving concepts in trauma care. Am Surg 1991;57:126-8.

9. Malhotra AK, Fabian TC, Katsis SB, Gavant ML, Croce MA. Blunt bowel and mesenteric injuries: the role of screening computed tomography. J Trauma 2000;48:991-1000. CrossRef

10. Sharma OP, Oswanski MF, Singer D, Kenney B. The role of computed tomography in diagnosis of blunt intestinal and mesenteric trauma (BIMT). J Emerg Med 2004;27:55-67. CrossRef

11. Meyer DM, Thal ER, Weigelt JA, Redman HC. Evaluation of computed tomography and diagnostic peritoneal lavage in blunt abdominal trauma. J Trauma 1989;29:1168-72. CrossRef

12. Rozycki GS, Ochsner MG, Jaffin JH, Champion HR. Prospective evaluation of surgeons' use of ultrasound in the evaluation of trauma patients. J Trauma 1993;34:516-27. CrossRef

13. Dolich MO, McKenney MG, Varela JE, Compton RP, McKenney KL, Cohn SM. 2,576 ultrasounds for blunt abdominal trauma. J Trauma 2001;50:108-12. CrossRef

14. Bode PJ, Edwards MJ, Kruit MC, van Vugt AB. Sonography in a clinical algorithm for early evaluation of 1671 patients with blunt abdominal trauma. AJR Am J Roentgenol 1999;172:905-11. CrossRef

15. Coley BD, Mutabagani KH, Martin LC, Zumberge N, Cooney DR, Caniano DA, et al. Focused abdominal sonography for trauma (FAST) in children with blunt abdominal trauma. J Trauma 2000;48:902-6. CrossRef

16. Miller LA, Shanmuganathan K. Multidetector CT evaluation of abdominal trauma. Radiol Clin North Am 2005;43:1079-95. CrossRef

17. Bhagvan S, Turai M, Holden A, Ng A, Civil I. Predicting hollow viscus injury in blunt abdominal trauma with computed tomography. World J Surg 2013;37:123-6. CrossRef

18. Brofman N, Atri M, Hanson JM, Grinblat L, Chughtai T, Brenneman F. Evaluation of bowel and mesenteric blunt trauma with multidetector CT. 
Radiographics 2006;26:1119-31. CrossRef

19. Landis JR, Koch GG. The measurement of observer agreement for categorical data. Biometrics 1977;33:159-74. CrossRef

20. Tieng N, Grinberg D, Li SF. Discrepancies in interpretation of ED body computed tomographic scans by radiology residents. Am J Emerg Med 2007;25:45-8. CrossRef

21. Yoon LS, Haims AH, Brink JA, Rabinovici R, Forman HP. Evaluation of an emergency radiology quality assurance program at a level I trauma center: abdominal and pelvic CT studies. Radiology 2002;224:42-6.

22. Ranschaert ER1, Binkhuysen FH. European Teleradiology now and in the future: results of an online survey. Insights Imaging 2013;4:93-102.

23. Platts-Mills TF, Hendey GW, Ferguson B. Teleradiology interpretations of emergency department computed tomography scans. J Emerg Med 2010;38:188-95. CrossRef

\section{KLINIK ÇALIŞMA - ÖZET}

\section{Künt travma sonrası bağırsak ve mezenter yaralanmalarında çok kesitli bilgisayarlı tomografinin tanısal etkinliği ve tecrübenin önemi}

\section{Dr. Ahmet Veysel Polat, ${ }^{1}$ Dr. Ramazan Aydin, ${ }^{2}$ Dr. Mehmet Selim Nural, ${ }^{1}$ Dr. Selim Baris Gul, ${ }^{1}$ Dr. Ayfer Kamali Polat, ${ }^{3}$ Dr. Kerim Aslan ${ }^{1}$}

${ }^{1}$ Ondokuz Mayıs Üniversitesi Tıp Fakültesi, Radyoloji Anabilim Dalı, Samsun;

${ }^{2}$ Samsun Eğitim ve Araştırma Hastanesi, Radyoloji Kliniği, Samsun;

${ }^{3}$ Ondokuz Mayıs Üniversitesi Tıp Fakültesi, Genel Cerrahi Anabilim Dalı, Samsun

AMAÇ: Çalışmamızda künt bağırsak ve mezenter yaralanmalarında (KBMY), çok kesitli bilgisayarlı tomografinin (ÇKBT) tanısal etkinliğinin ve farklı düzeydeki radyolog tecrübesinin tanıya katkısının değerlendirilmesi amaçlandı.

GEREÇ VE YÖNTEM: Çalışma grubuna travma nedeniyle cerrahi uygulanan ve klinik önemli KBMY olduğu doğrulanan ve ameliyat öncesi BT incelemeleri mevcut olan 27 hasta (23 erkek, 4 kadın, ort. yaş 40.77 I 6.2 yıl; dağılım I8-76 yıl) alındı. Kontrol grubu olarak da yine aynı dönemde BT incelemesi mevcut olan ve cerrahi sonrası KBMY olmadığı doğrulanmış 2 I hasta ( 16 erkek, 5 kadın, ort. yaş 38.9 I I4.5; dağııı, 20-68) alındı. Cerrahi öncesi 16 kesitli ÇKBT ile yapılan incelemeler ameliyat bilgileri bilinmeksizin tekrar yorumlandı. ÇKBT bulguları ameliyat bulguları ile karşılaştırıldı. BULGULAR: Çok kesitli bilgisayarlı tomografi bulguları içinde; intraperitoneal serbest hava, mezenterik hava, bağırsak duvarında kalınlaşma (>4-5 mm), bağırsak duvarında kontrastlanma artışı, bağırsak duvarında defekt ve mezenterik hematom bulgusu, doğruluk, özgüllük ve pozitif öngörü değer bakımından yüksek bulundu $(\mathrm{p}<0.01)$. KBMY doğru tanı koyabilmede kıdemli radyoloji asistanı ve abdomen tecrübeli radyolog arasında duyarlılık ve özgüllük sırasıyla \%74, \%7। ve \%85, \% 100 bulundu.

TARTIŞMA: Çok kesitli bilgisayarlı tomografi, KBMY'yi yüksek duyarlılık ve özgüllük ile gösterebilir ve cerrahi gerekliliğini öngörebilir. Radyolojideki tecrübe ÇKBT'nin doğru raporlanmasında önemli bir faktördür.

Anahtar sözcükler: Bağırsak yaralanması; çok kesitli bilgisayarli tomografi; künt karın travması.

Ulus Travma Acil Cerrahi Derg 20।4;20(6):4I7-422 doi: I0.5505/tjtes.20।4.52959 